\title{
Victoria regia's bequest to modern architecture
}

\author{
D. Nielsen \\ Queensland University of Technology, Australia
}

\begin{abstract}
This paper will explore the relationship between the giant South American water lily, the Victoria regia (today named Victoria amazonica), and the 1914 Glashaus exposition building by the German architect, Bruno Taut.

Starting with a general botanical introduction of Victoria regia, the paper exposes the first European cultivation of the lily by Joseph Paxton at Chatsworth, England, in 1849. Following this initial cultivation, Paxton subsequently develops a specialist greenhouse for the plant, that later becomes the prototype for all Victoria regia greenhouses. However, from about 1860 as Victoria regia cultivation spreads to continental Europe, a greenhouse that differs from Paxton's prototype subsequently evolves. An investigation of these later continental European greenhouses, coupled with an exposure of Taut's own writings concerning Victoria regia, reveals startling similarities to the Glashaus, which ultimately reveals the Glashaus as directly inspired by Victoria regia.
\end{abstract}

Keywords: Victoria regia, Bruno Taut, Glashaus, Joseph Paxton.

\section{Introduction}

One result of colonialism was the return of exotic Flora to the European context. On one level, exotic Flora was returned as a curiosity to be admired, while on a more important level, Flora were also returned in an attempt to discover their potential for future economic exploitation [1]. As a result, the desire to scientifically study and propagate these exotic species became increasingly important. However, the European climate was largely unsuitable for plants sourced from diverse climatic regions. Greenhouses were developed in an attempt to artificially recreate the desired climatic conditions for the propagation of exotic Flora.

Initially only 'smaller' species like citrus were collected and propagated, but as European colonialism and industrialisation aggressively progressed, the desire 
to collect even larger plant specimens, as part of ever increasing collections, also increased. This in turn resulted in more numerous, larger and increasingly complex greenhouses. Along with the Palm Houses, that contained the largest or tallest of species, a proliferation of equally specific and functionally optimised greenhouses, such as Camellia Houses, Lily or Aquatic Houses and Orchid Houses, also resulted. After the initial European cultivation of the Victoria regia (VR) lily in 1849, a specific greenhouse, the VR House, was also subsequently developed [2].

Greenhouses generally acquired their names according to rational scientific classification; either botanically according to their wider Family (Palm Houses), or a sub-family or Genus, (Camellia and Lily Houses); alternatively, greenhouses were also named geographically, according to their original climatic regions (Sub-tropical Houses). The naming of an entire greenhouse according to a specific Species (VR House) was extremely uncommon, and this would tend to indicate that there is something extraordinary concerning this Species.

\section{Victoria regia and its initial cultivation in Europe}

Belonging to the Genus Victoria and the Family Nymphaeaceae, VR (now referred to as Victoria amazonica) is a native species of South American water lily [3]. What is remarkable about VR (Fig. 1) are its sheer size, rapid growth patterns and intriguing pollination habits. The first European to discover VR, Thaddäus Haeneke, is said to have fallen to his knees in admiration at the first sight of VR in flower [4]. French naturalist Alcide d'Orbigny is quoted as describing the VR as being, without a shadow of doubt, the most exquisite plant known to Europeans; because of its overall composition of leaves, flowers, size, colour and elegant location in the water [4]. This sentiment is later shared by Robert Schomburgk when he encountered the VR in 1842, describing it as one of the grandest productions of the botanic kingdom owing to the superior magnificence of its leaves and the splendour of its flowers and associated fragrance [4].

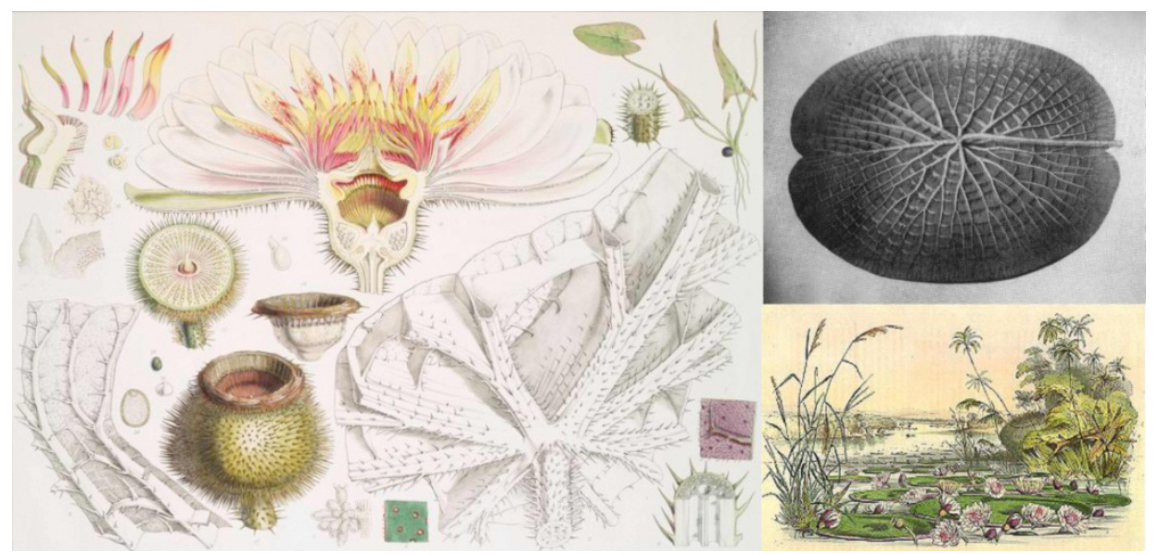

Figure 1: $\quad$ Historical illustrations depicting the Victoria regia lily [5]. 
In its natural environment, the leaves of VR are recorded in 2006 as measuring a massive 2.7 meters $(\mathrm{m})$ in diameter [5]. When first cultivated outside of it natural habitat, the leaves of the VR reached a maximum diameter of six and a half feet (') (1.98m). The structure of the leaves is equally impressive. According to an 1850's description of the VR [6], when a new leaf first breaks the surface of the water, it is initially an inverted red-brown mass covered in spines that slowly unfurls to reveal an upper smooth green surface with a prominent upturned rim. The red-brown or deep purple underside of the leaf consists of a prominent lattice or structure of air filled members. Eight primary members radiate from a central stem point that them subdivided into numerous smaller radial members. Perpendicular to these main radial members are concentrically arranged struts that divide the lower surface of the leaf into quadrangular chambers. Covering all these structural members are prominent spines. In a similar manner as the leaf, the flower initially breaks the surface of the water as a pear-shaped bud furnished with a dark brown protective cover, also covered by protective spines. The flower being nocturnal, first blooms at about five in the evening and is a brilliant white colour and approximately 25 to 38 centimetres $(\mathrm{cm})$ in diameter when fully unfurled [6]. Additionally, the flower is strongly pineapple scented, and as the flower blooms it supposedly raises it internal temperature through a thermo-chemical reaction [7]. This scent is said to attract a specific species of large flying beetle that pollinates the flower. The flower closes on the morning of the second day, capturing numerous beetles that are still active with pollination. On the second evening the flower once again opens and releases the captive beetles. The flower is now a transformed from an initially brilliant white to a pinkish rose colour. At about $23 \mathrm{H} 00$ on the second night, the flower closes permanently and sinks below the surface of the water to develop its seeds [6].

In the $19^{\text {th }}$ century Joseph Paxton, as the Head Gardener for the Duke of Devonshire at his Chatsworth Estate, was considered an eminent cultivator of exotic plants. Owing to his status, Paxton personally obtained a VR seedling from the Royal Botanical Gardens at Kew on $3^{\text {rd }}$ August 1849 [8]. Initially the VR seedling was placed in a 12 foot-square $\left(1.1 \mathrm{~m}^{2}\right)$ heated tank that was protected by a curvilinear roofed greenhouse [9]. In 1836 Paxton tests a

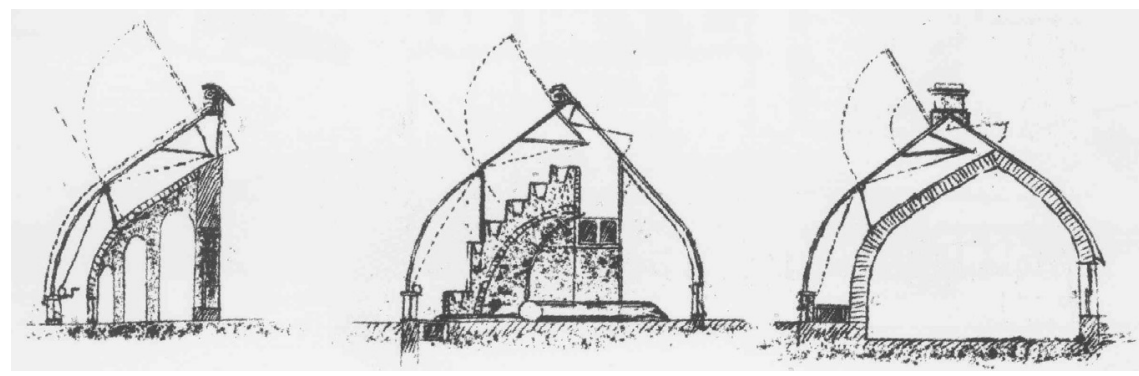

Figure 2: $\quad$ Sectional drawing through forcing-houses by Loudon [19]. 
curvilinear pleated (ridge-and-furrow) roof on a 60x26' (18.3x7.925m) forcinghouse, and this becomes the initial home for VR until the construction of a later specific greenhouse in 1849 [1]. While no illustration can be found of this initial greenhouse, it could be reasonably argued it followed the accepted convention of the period as earlier established by John Claudius Loudon in 1817 (Fig. 2).

In this artificial environment VR did phenomenally well, and a mere six weeks after its initial planting the leaves measured $3^{\prime} 6^{\prime \prime}(1.07 \mathrm{~m})$ in diameter. On $1^{\text {st }}$ October the leaves had increased to $4^{\prime}(1.22 \mathrm{~m})$ in diameter, and by $15^{\text {th }}$ October to 4' 5" (1.35m) [8]. At this stage VR outgrew its initial pool and had to be relocated to a larger tank, which is twice the size of the first [9]. Continuing its phenomenal growth, VR outgrows its pond on a further two occasions [10]. VR flowers for the first time in Europe during 8-10 ${ }^{\text {th }}$ November 1849, and Paxton personally presents one of its initial flowers and a large leaf to Queen Victoria on $15^{\text {th }}$ November 1849 [9].

Having discovered VR's cultivation requirements in the experimental forcinghouse, Paxton then constructs a purpose built greenhouse (Fig. 3), started in the 1849 but only completed in the spring of 1850 [11]. The plan dimensions of this building are described as measuring either $61 \times 49^{\prime}(18.6 \times 14.94 \mathrm{~m})$ [10] or $62 \times 54^{\prime}$ $(18.9 \times 16.46 \mathrm{~m})$ [1]. At the centre of this rectangular plan, a circular pond for VR was located; measuring either 33' $(10.05 \mathrm{~m})$ [10] or $40^{\prime}(12.19 \mathrm{~m})$ [1] in diameter. The main pond had a deeper central portion measuring $16^{\prime}(4.88 \mathrm{~m})$ which contained the soil for the VR. Eight smaller ponds were additionally located in the corners of the house; these contained other exotic aquatic species like Nymphaea, Nelumbium and Pontederia [11]. Sitting on almost square masonry foundations, the building consisted of a masonry base that rose 37 " $(94 \mathrm{~cm})$ from the ground. Contained within this base were the raised ponds, their heating pipes and low-level ventilation openings [1]. Four inch $(10 \mathrm{~cm})$ iron heating pipes were embedded in the deep central soil, while two inch $(5 \mathrm{~cm})$ lead pipes were placed in the shallower potion of the pond. The atmosphere within the house was heated by four inch $(10 \mathrm{~cm})$ iron pipes that ran between the piers of the basement wall. Air flowed into the house through 30 low-level openings in the basement wall, over the heating pipes and out through roof opening operated by simple machinery. Within the pond, four small waterwheels added gentle motion to the water, while

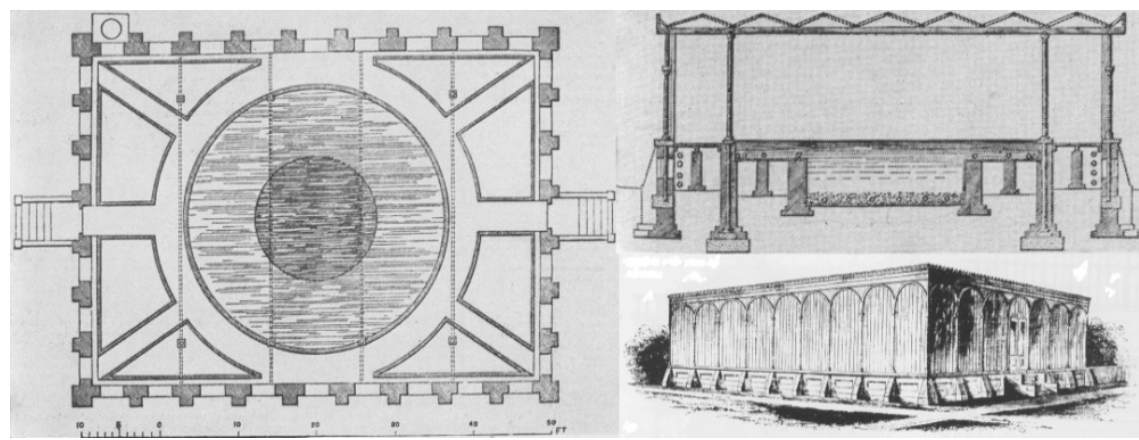

Figure 3: Joseph Paxton's purpose built Victoria regia House [11]. 
above each waterwheel was a supply of cold water to 'normalise' the temperature of the pond as required [11]. Above the masonry base, Paxton's VR House extended upward in glass, wood and steel. The main vertical structural façade consisted of cast-iron columns at six feet $(1.83 \mathrm{~m})$ intervals topped with rounded arches. Behind this cast-iron façade, was a secondary structure of vertical glazing that consisted of wooden sash bars containing $5 \times 10 "(13 \times 26 \mathrm{~cm})$ glass panes. The horizontal glazed roof of the building was a ridge-and-furrow system, with a parallel Paxton Gutter below in the valleys or furrows. Before this VR House, Paxton had used his Gutter as the main structural support to the ridge-and-furrow roof. Paxton now developed an independent structural support system that ran perpendicular, to both the Gutter and the ridge-and-furrow. This comprised four 54' (16.46m) wrought-iron master joists that were five inches $(13 \mathrm{~cm})$ deep with the addition of one inch $(2.5 \mathrm{~cm})$ diameter steel tie-rods below. Supporting each of the master joists were two hollow $3.5^{\prime \prime}(9 \mathrm{~cm})$ cast-iron columns [1]. In his VR House, Paxton develops a hierarchy in the horizontal space-frame through the development of distinct structural and cladding systems, and one could rightly enquire as to why he did this. On previous occasions Paxton is impressed by the massive carrying capacity of the VR leaves. In 1849 after the VR initially blooms, Paxton places his seven year old daughter Annie on a VR leaf, a weight it carries with ease. Again in early May of 1850, Paxton conducts the same experiment in a small stream near the Kitchen Gardens at Chatsworth with a leaf of five feet $(1.52 \mathrm{~m})$ in diameter. For this later experiment, Paxton constructs a lightweight circular trellis that is placed on the leaf surface so as to distribute any applied weight evenly. On to this trellis, Paxton places 112 pound (51 kilograms $(\mathrm{kg})$ ) weights before water started to flow over the upturned edges. After the weights are removed, two men of approximately 10-11 stone $(63.5-70 \mathrm{~kg})$ are each carried by the leaf for a period of between two and three minutes [4]. On $13^{\text {th }}$ November 1850 [11] Paxton, in an appearance at the Royal Society of Arts, presents a series of drawings of his Crystal Palace building. Along with the drawings, Paxton also presents a leaf from his VR lily which he notes the underside as being an excellent example of natural engineering: “...in that the cantilever that radiate from the centre, where they are nearly two inches deep, with large bottom flanges and very thin middle rib, and with cross girders between each pair to keep the middle ribs from buckling..." [12] Paxton admits that the origin of Crystal Place derives from his gardening experiences, particularly from the greenhouse that he built for VR [13]. Or, alternatively as Fay quotes: "...to this plant and to this circumstance that the Crystal Palace owes its direct origin" [14].

The leaf of VR proves to Paxton that both his ridge-and-furrow (representing the leaf surface) can be fully supported on a Gutter (radial structure) as long as it is cross braced with master joists (concentrically arranged struts) to prevent buckling. This ultimately divides the structure into quadrangular chambers, just like the leaf of VR.

On $10^{\text {th }}$ April 1850, a Mr. Ivison, working for the Duke of Northumberland at his Syon Estate, became the second person to successfully bring VR to bloom [6]; while the third to flower is a specimen at the Royal Botanical Gardens at 


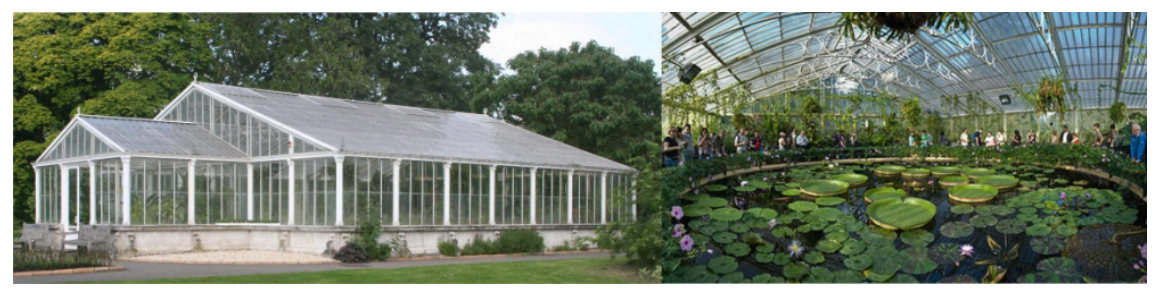

Figure 4: $\quad$ Victoria regia House at Royal Botanical Gardens, Kew [21].

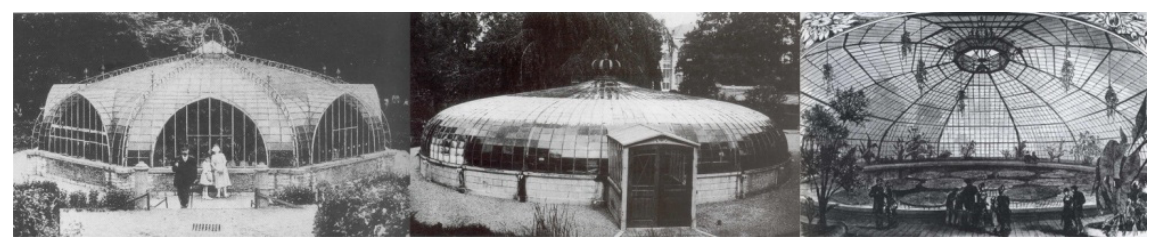

Figure 5: Examples of continental European Victoria regia Houses, from left to right: Balat's 1854 House [2], the 1870 example at Leyden University [2], and the 1882 example at the old Royal Botanical Gardens in Berlin [21].

Kew [4]. At Kew, the VR House (Fig. 4) was originally designed by Richard Turner in 1850 and is 46x46' $(14 \times 14 \mathrm{~m})$ wide by $20^{\prime}(6.1 \mathrm{~m})$ high. The building consists of a regular glazed ridge roof supported on triangular trusses that comprise reinforcing elements comprising circular round steel bars [1]. A simple comparison between the Kew VR House and that of Paxton (Fig. 3) at Chatsworth reveals that they both share the same basic design. As such, these two British examples could therefore be presented a typical of VR Houses of this initial period.

\section{European examples of Victoria regia houses}

From this point onwards, VR spread rapidly to continental Europe and beyond [9]. On the $5^{\text {th }}$ of September 1850, from a seedling obtained by Eduard Ortgies, VR blooms for the first time on Continental Europe in Belgium. Ortgies has a direct relationship with Paxton owing to his prior employment at Chatsworth, in which he is directly responsible for the day-today care of Chatsworth VR under the overall direction of Paxton. This first continental European blooming is at the horticultural business of Louis van Houtte and takes places in a glass house specifically constructed for it according to Ortgies' plans [5]. While no information concerning the specific construction of this house can be found, it is highly probable, owing to Ortgies' connection to Paxton that it is of a similar design as the earlier British examples. VR blooms for the first time in Germany in 1851 at the Berlin Estate of the Steel magnate Johann Borsig, in an elegant glass temple constructed of dainty iron rods [15]. In 1859 VR blooms in Amsterdam at the Hortus Botanicus [2]. 
From about 1860, numerous VR Houses are built in continental Europe that differ from the earlier British examples in having a circular or polygonal plan shape and covered by a flattish curved glazed dome. This planning and resultant form arrangement becomes typical of continental European VR Houses [1]. An early 1854 example of this 'regular polygon' type by the Belgian architect Alphonse Balat (Fig. 5) is located at the Botanical Gardens of Brussels [2]. This example comprised an eight sided regular octagon plan, with a low stone plinth and a flat glazed dome above. The main structure, comprising exposed curved iron trusses, rises from the plinth's corners and then culminates at the apex in an elaborate iron crown. What is interesting about this example, are the eight vertical gable-end windows that intersect the flat dome. An 1870 example, that is also typical of continental European VR Houses, was located at the famous gardens of the Leyden University (Fig. 5), and appears to have a 24 or 20 sided plan [2]. While this building's iron and glass form is generally devoid of any decoration, it shares a large apex ironwork crown with Balat's earlier example. In 1882, a further VR House (Fig. 5) following the 'regular polygon' type was built at the old Royal Botanical Gardens, in Berlin. This 1882 house had a regular 10 sided decagon plan with a $3^{\prime}(95 \mathrm{~cm})$ high masonry plinth at the base. At the centre of the plan was the main pool for VR, with a secondary concentric circular pool along the perimeter, for smaller exotics. A system of cooper pipes was laid along the walls and inside plinth to the ponds to heat the water. A flattish glazed dome, which comprised a main structure of ten rolled I-beams, rose from the corners of the decagon plinth to a central ring-beam arrangement commonly referred to as a 'lantern' or 'accumulated apex'. This lantern comprised a ten sided purlin structure with glass in-filled louvers for ventilation. At the base of the dome were ten further low-level ventilators. Reinforcing the ten I-beams was a stiffening structure comprising parallel iron purlins. Infilling the main structure was secondary glazing structure comprising iron glazing bars and panes of doppelglas (double glazing) [1].

Arguably the prototype of these continental European examples is an 1822 design for a 'Mechanical Aquatic House' (Fig. 6) published by J.C. Loudon in his 1822 book, An Encyclopaedia of Gardening [17]. This published, but never built, proposal consisted of a circular plan that contained a central pond for river plants and an outer pond along the periphery for plants that grew in still water. The central pond was agitated via a 'wind-up-jack' mechanism that effetely
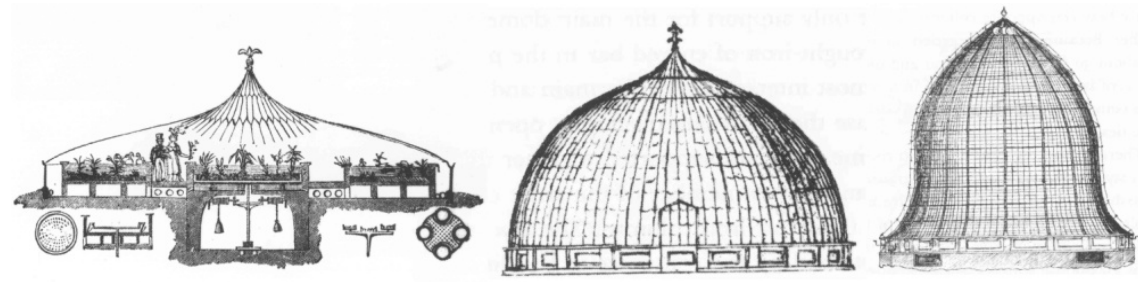

Figure 6: J.C. Loudon's earlier proposals for the Mechanical Aquatic House (left) [17], and 1817 hemispherical (middle) [20] and bell-shaped (right) [20] glazed domes for conservatories. 
rotated the entire base of the pond. Plants that thrived in more rapid waters were to be placed at the edge of the rotating base. The glass envelope was curved low over the outer pond for shorter exotics, while at the centre it gained height to accommodate taller species. In addition to the rotation mechanism, a furnace was located in the chamber below the central pond. Like the 1854 and 1870 houses before (Figs. 5), the glazed apex of the dome had a figurine, and like Paxton's VR House (Fig. 3) there appears to be heating pipes below the boardwalk, between the two ponds. The 'Mechanical Aquatic House' proposedly evolves out of Loudon's earlier 1817 proposals (Fig. 6) for hemispherical and bell-shaped domes published in his Remarks on the Construction of Hothouses [1].

\section{Bruno Taut's Glashaus}

Bruno Taut's Glashaus exhibition building (Fig. 7) is an extremely influential example of early modernist architecture. Since its construction at the 1914 Werkbund Exhibition in Cologne, Germany, the building and the circumstances surrounding its creation has been the subject of intense debate. This debate is primarily contextualised within the buildings exemplar status being questioned owing to its very short lifespan of a few weeks, the collaborative nature of the project and to what degree previous buildings by Taut and his peers influenced its construction. To the best of the author's knowledge, no investigation has yet exposed the relationship between VR and the Glashaus.

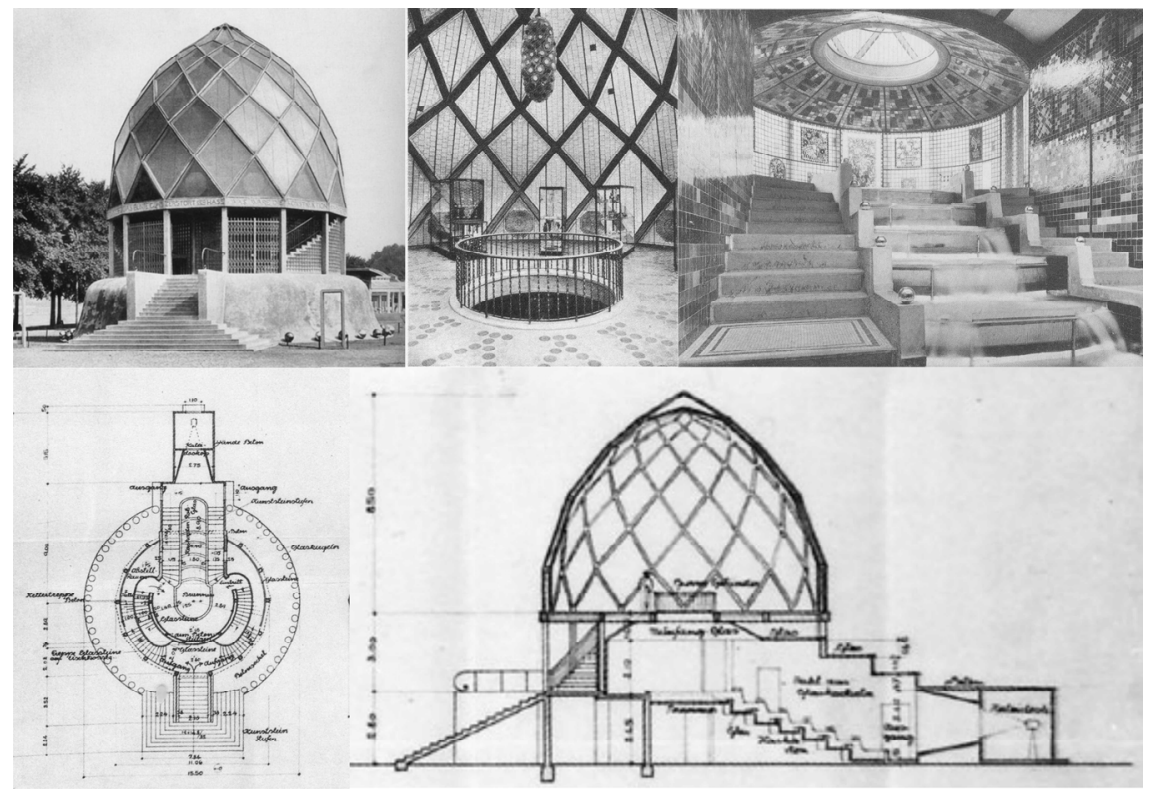

Figure 7: Bruno Taut's Glashaus. Images read clockwise from top left, exterior [21], interior of the glazed cupola room or dome room [21], the cascade room below the dome room [21], longitudinal section [22], and plan [22]. 


\section{Victoria regia, Bruno Taut and the Glashaus}

On $8^{\text {th }}$ July 1920, Taut writes a film script: Die Galoschen des Glücks (The Lucky Shoes) [18]. The script starts with the description of a desolate unemployed youth in a blighted urban industrial landscape. In an attempt to escape this environment, the youth decides to relocate to the country-side. On his arduous journey out of the city, along an endless highway, the youth encounters the 'shoes of fortune'. After the youth tries these shoes on, everything changes; rags become splendid clothing, the road becomes lined with trees and is now bathed in bright sunshine and fresh air. Continuing along the highway the youth enters a wooded area, in which he discovers a clearing. At the edge this clearing, surrounded by glittering, sparkling trees, is a building that appears to be both man made and a product of nature. Standing in front of the building in amazement, the youth claps his hands, it opens and a man steps out to greet him. The man invites the youth into the building that is filled with family, hospitality and purity, and decorated with flowering growths of stone and glass. The man then leads the youth upward into a room of glass were he points outward to the glittering woods. As the man's wife enters the room her features reminds the youth of a previous association, and the youth starts to cry. In an attempt to consol the youth the man leads him in a wondrous chamber that contains “...many strange growths, great floating leaves (like Victoria Regia) and many others" [18]. The man then takes a peculiar rod and excites the growths with its point, "... and out of the leaves grow houses... as sparkling and dreamlike as his own, like opalescent domes, butterfly-wing buildings - oh, inexpressible - a fairy-tale city reflected in the water, ravishingly beautiful." [18]. Overpowered, the youth loses consciousness and later wakes up once again on the initial bleak desolate highway...

To argue the first portion of Die Galoschen des Glücks as being synonymous with Taut's career to date is highly probable. A closer examination of the script reveals startling similarities to Taut's own interests and concerns with architecture and the rapid industrialisation and subsequent urbanisation of Germany. The youth can be presented as a character representing Taut. The script starts in an industrial rapidly urbanising city, possibly Berlin. In an attempt to mediate or mitigate the worst effects of industrialisation, Taut, through his actual interests in urban panning issues and particularly the German Garden City Movement, seeks the reintroduction of 'nature' into cities. The journey out of the city could be argued as synonymous with this quest. Arguably for Taut, the architectural elements that represent 'nature' in the industrial city are botanical greenhouses; this notion could be argued as synonymous with glittering woods and the house that grows from the earth, in the script. Alternatively, it could be the discovery of the 'shoes of fortune'. The man that meets Taut can be argued as being the character for Scheerbart, who is instrumental in introducing Taut to botanical greenhouse architecture. The building that they initially enter could be presented as a Gothic Cathedral. Both Taut's and Scheerbart's interest in Gothic architecture is well documented, and both see Gothic architecture as the initial step in the development of their new glass architecture. The second room that 


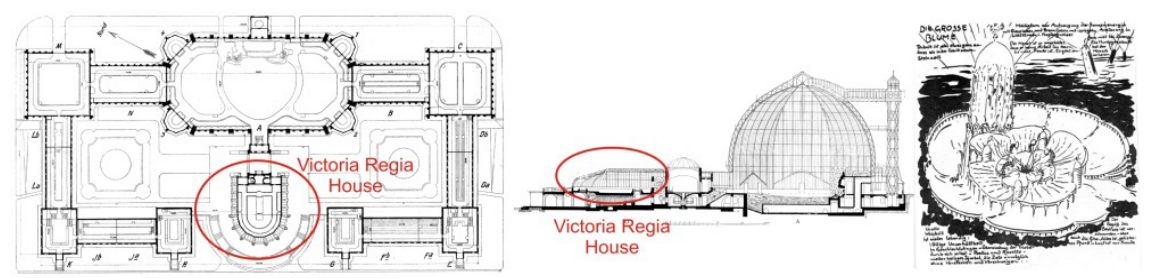

Figure 8: Composite image, read from left to right: Plan [21] and section [21] of the Great Palm House complex at the Berlin Royal Botanical Gardens indicating the Victoria regia House, and Bruno Taut's Die Große Blume [23].

they enter, could be the next evolution of this new evolving glazed architecture, and can be interpreted as either generally synonymous with a botanical greenhouse, or specifically as The Great Palm House (Fig. 8) at the new location for the Royal Botanical Gardens, in the Berlin suburb of Dahlem. This last contention is due to the fact that Scheerbart specifically mentions this building in his 1914 book Glasarchitektur [19], which he dedicates to Taut and Taut dedicates the Glashaus to Scheerbart. The final room that they enter could very reasonably be a VR House, in which Scheerbart introducing Taut to VR and shows him how glazed buildings are created from its leaves. In the Great Palm House complex at Dahlem, leading off from the main greenhouse, are a series of smaller houses, including as specific and prominently shaped VR House (Fig. 8). In the case of Taut, the 'opalescent domes, butterfly-wing buildings' that result from VR's leaves can only be his Glashaus. While the 'fairy-tale city reflected in the water' is indeed to be found in Taut's Die Große Blume (The Big Flower) (Fig. 8) illustration, published in his 1920 work, Die Auflosung der Stadte (The Dissolution of the Cities) [23]. The script then abruptly concludes this glorious period in Taut's life with the outbreak of the First World War, in this case being synonymous with once again being on the bleak desolate highway...

\section{Discussion}

By connecting the Glashaus to existing precedents of the continental European example of VR Houses, the question of what ultimately lies behind the Glashaus is answered. It is proposed that the overall forms of both buildings are similar: Outwardly both are stand-alone pavilion type buildings, and both have a low squat solid base that contains the pools and mechanical equipment needed to maintain them. Both have distinct entrances that rise upward through the base. Both have glazed curved domes which spring from the base, are highly faceted and are arguably the main features of the buildings. Additionally, both domes have a 'lantern' or 'accumulated apex' at the top of the dome. Both plans are based on regular polygon arrangements, and both have a deep central 'pool' to their designs. In the case of the Glashaus, the 'pool' could either be the physical cascade or the oculus that connects the dome room to the cascade room below. The general circulation of the Glashaus can be compared to Paxton's VR House, 
in that the circulation is both axial and circular. The main reinforced concrete structure of the dome over the Glashaus is arguably the equivalent of the underside of a VR leaf. Further, by comparing the cross section of the VR flower (Fig. 1) with that of the Glashaus, certain metaphors are apparent as concerns two distinct, but still connected spaces; one colourful light-filled space above with a darker, more intimate space below. However, it could be proposed that these arguments are still only circumstantial associations.

When the Glashaus is compared to the Dahlem VR House (Fig. 8), circumstantial associations become more concrete. The Dahlem VR House has seven distinct portions on its outer half-circle plan, forming half a tetradecagon; in contrast the Glashaus has exactly twice this number forming a 'full' 14 sided tetradecagon plan. Of further interest are the two semicircular staircase that lead from the lower level of the Dahlem gardens upward to the VR House on the upper level; this arrangement is distinctly similar to the staircases in the Glashaus. Also of significance are the lower and upper floors in the Dahlem example. To enter the VR House, the visitor can proceed from either the lower gardens or the main Palm House; this entails either entering the darker grotto like lower floor (if entering from the lower gardens), or down a flight of stairs and then across a brightly lit double-volume space (if entering from the main Palm house). These two routes then converge at a central point that proceeds upward, via a set of curving stairs, to the VR House above. This route is once again distinctly similar to that of the Glashaus, in that the visitor proceeds up an initial flight of stairs contained in the base, and then enters the building by climbing the semicircular stairs that lead ultimately to the brightly lit dome area above. From here the visitor progresses downward via a different set of semicircular stairs into the darker cascade room. Following the cascade downward the visitor is lead into the shadowy, more constricted and linear kaleidoscope room, and then eventually to the exit.

\section{Conclusion}

The association of the Glashaus with botanical metaphors is not an entirely unique concept. In bad weather the reflecting glazed facets of the Glashaus dome assumed a greenish-yellow colour; this resulted in the visiting public naming the building 'Asparagus-head'. Alternatively, when approached from a distance the Glashaus supposedly looked like a sprouting seed, or a flower bud that was about to bloom [24]. But, these are only simplistic metaphorical associations. From the argument presented above, in addition to simplistic metaphors, Bruno Taut's Glashaus now has specific botanic origins - VR origins.

\section{References}

[1] Kohlmaier, G., \& Sartory, B. v., Houses of Glass: a Nineteenth-century Building Type, MIT Press: Cambridge, Massachusetts, 1986.

[2] Hix, J., The Glasshouse, Phaidon: London, 2005. 
[3] Genus; Victoria Lindl, Germplasm Resources Information Network, United States Department of Agriculture, Online. http:/www.ars-grin.gov/cgibin/npgs/html/genus.pl?12702

[4] Allen, J. F., Victoria Regia, or the Great Water Lily of America, Dutton and Wentworth: Salem, Massachusetts, 1854.

[5] Victoria Adventure, Victoria, Online. http://www.victoriaadventure.org/victoria/victoria index.html

[6] Authors Unknown, Victoria Regia. The Gardeners Chronicle, pp. unknown, 1850.

[7] Schrader, D., Extraordinary Leaves, Firefly Books: Buffalo, New York, 2008.

[8] Cavendish, D. V., (1999). The Duchess of Devonshire: The Gardens at Chatsworth, Francis Lincoln: London, 1999.

[9] Flanders-Darby, M., Joseph Paxton's Water Lily. Bourgeois and Aristocratic Cultural Encounters in Garden Art, 1550-1850, ed. M. Conan, Dumbarton Oaks Research Library and Collection: Washington, 2002.

[10] Markham, V., Paxton and the Bachelor Duke, Hodder \& Stoughton Limited: London, 1935.

[11] Chadwick, G., (1961). The Works of Sir Joseph Paxton, 1803-1865, Architectural Press: London, 1961.

[12] Paxton, J., Lecture to the Royal Society of Arts. Transactions, Vol.57, pp.1, 1850-51.

[13] Ersoy, U., Seeing Through Glass: The fictive Role of Glass in Shaping Architecture from Joseph Paxton's Crystal Palace to Bruno Taut's Glashaus, University of Pennsylvania: Philadelphia, 2008.

[14] Fay, C.R., Palace of Industry, 1851: a Study of the Great Exhibition and its Fruits, Cambridge University Press: Cambridge, pp. 11, 1951.

[15] Freie Universität Berlin, Botanical Garden and Botanical Museum BerlinDahlem, Online. http://www.bgbm.org/bgbm/default_e.htm

[16] Loudon, J.C., An Encyclopaedia of Gardening, Longman, Rees, Orme, Brown and Green: London, 1822.

[17] Taut, B., Die Galoschen des Glücks. The Crystal Chain letters: Architectural Fantasies by Bruno Taut and his Circle, ed. I.B Whyte, MIT Press: Cambridge, Massachusetts, pp. 118-122, 1985.

[18] Scheerbart, P., Glasarchitektur. Strum: Berlin, 1914.

[19] Loudon, J.C., Remarks on the Construction of Hothouses, Richard and Arthur Taylor: London, 1817.

[20] Wikimedia Commons, A Database of Freely Useable Media Files, Online. http://commons.wikimedia.org/wiki/Main_Page

[21] Taut, B., Glashaus Koln. Cologne, Germany, 1914.

[22] Taut, B., Die Auflosung der Stadte, Folkwang: Hagen, 1920.

[23] Thiekotter, A., Kristallisationen, Splitterrungen: Bruno Taut's Glashaus, Birkhauser Verlag: Basel, 1993 